\title{
Aluminium release by water-rock interaction during hydraulic tests in a siliciclastic aquifer in Berlin (Germany)
}

\author{
Simona Regenspurg ${ }^{1, *}$, Guido Blöcher ${ }^{1}$, Stefan $\mathrm{Kranz}^{1}$, and Ali Saadat ${ }^{1}$ \\ ${ }^{1}$ GFZ German Research Centre for Geosciences, D-14473 Potsdam, Germany
}

\begin{abstract}
Two hydraulic tests of a Triassic sandstone aquifer were performed to determine hydraulic and geochemical parameters of the reservoir formation. Samples collected during all tests showed neutral and constant $\mathrm{pH}$-value of about 7.5. During the initial step rate test, the aluminium concentration of the water remained below $0.005 \mathrm{mM}$, but it increased significantly during the production phase of the following single well push-pull test to $4.8 \mathrm{mM}$. Drill cuttings of the well, collected at reservoir depth (Exter Fm. and the overlaying Tertiary sand), were additionally characterized and used for leaching experiments. These experiments evidenced a strong release of aluminium from the Tertiary, pyrite containing sand, indicating processes of pyrite oxidation being responsible for aluminium mobilization.
\end{abstract}

\section{Introduction}

In 2016 a research well (GtBChb 1/2015) was drilled to a depth of $259 \mathrm{~m}$ to investigate the possibility of using the Upper Triassic Exter sandstone as test site for aquifer thermal energy storage (ATES) in an urban area (Berlin, Germany). The Exter Fm. (Fig. 1) is represented by a grey, fine-grained to silty, poorly cemented, and well-sorted quartz sandstone interbedded with silty layers with the highest porosity of $30 \%$ between $221.7 \mathrm{~m}$ and $225.7 \mathrm{~m}$ depth [1]. This formation is separated from the hanging aquitard (Tertiary Rupelton Fm.) by a thin, sand and lignite containing, dark-brown Tertiary sand (TS) at a depth between 212.5 and $213.8 \mathrm{~m}$ that showed an artesian discharge during drilling [1]. Although only the section of the Exter Fm. was filtered between $220 \mathrm{~m}$ and $230 \mathrm{~m}$, a hydraulic connection between the two formations - either in the reservoir or via the gravel pack (Fig. 1) cannot be excluded.

\footnotetext{
*Corresponding author: regens@gfz-potsdam.de
} 


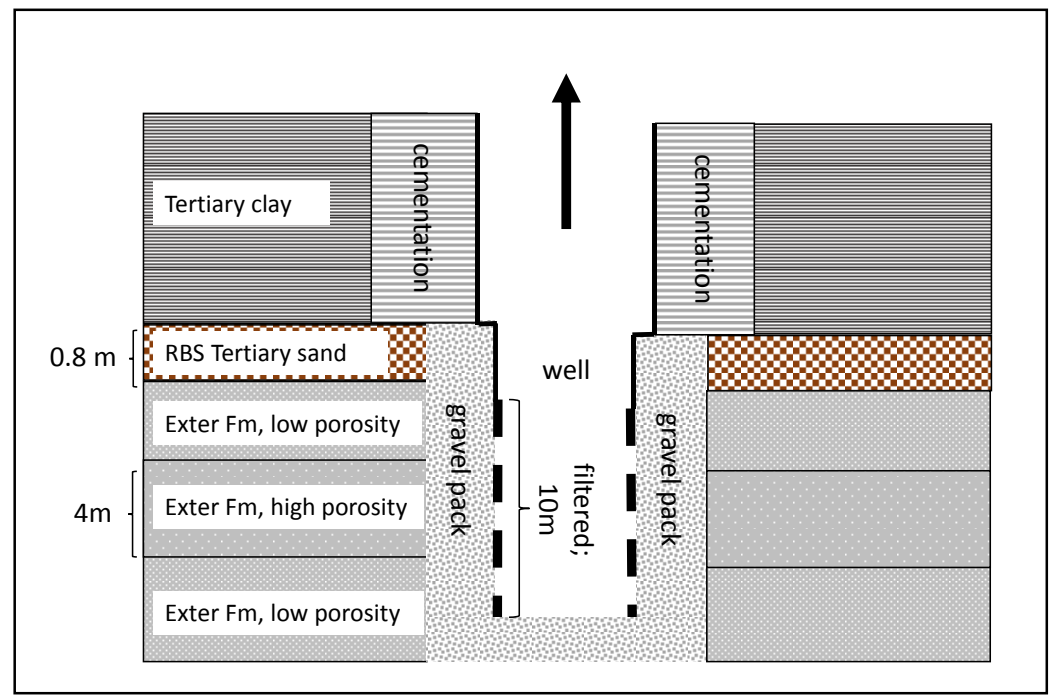

Fig. 1. Simplified scheme of the well (GtBChb 1/2015) and stratigraphic layers at near reservoir depth $(210-250 \mathrm{~m})$.

\section{Materials and Methods}

\subsection{Tests and water sampling}

For intermediate water storage of the step rate test (SRT) and the single well push pull test (PPT), three $28 \mathrm{~m}^{3}$ containers $(\mathrm{C} 1, \mathrm{C} 2, \mathrm{C} 3)$ were installed on the site. First, $37 \mathrm{~m}^{3}$ of groundwater was pumped out of the reservoir and discarded. Afterwards $\left(27^{\text {th }}\right.$ of September 2017), C1 and partly C2 were filled by producing $35 \mathrm{~m}^{3}$ water from the reservoir. The SRT started on the 28th of September 2017 by producing over 10 h subsequently 2, 3, 5, and 6 $\mathrm{m}^{3} / \mathrm{h}$ water (altogether $38.4 \mathrm{~m}^{3}$ ), which was filled into C2 and C3. Finally another $19.7 \mathrm{~m}^{3}$ were produced $\left(6 \mathrm{~m}^{3} / \mathrm{h}\right)$ and filled into C3. For the PPT, a tracer mixture (5992 g NaI, $160 \mathrm{~g}$ Eosine Y; $3396 \mathrm{~g} \mathrm{NaNO}_{3}$ ) was first dissolved in $250 \mathrm{~L}$ water, which was pumped into $\mathrm{C} 2$ and circulated there for a few hours. On the 4th of October 2017 the water was injected from the three containers into the reservoir (flow rate: $7 \mathrm{~m}^{3} / \mathrm{h}$ ) starting with $\mathrm{C} 1$ (no tracer), followed by the tracer-yielding $\mathrm{C} 2$ and finally by the water of the tracer-free $\mathrm{C} 3$ ("chaser"). Twelve hours later, the water was extracted $\left(6 \mathrm{~m}^{3} / \mathrm{h}\right)$ until $300 \mathrm{~m}^{3}$ water were removed.

During both, production and injection phase of the tests, samples were continuously collected and $\mathrm{pH}$-value, redox, electric conductivity, and $\mathrm{O}_{2}$ content were monitored. Bicarbonate $\left(\mathrm{HCO}_{3}{ }^{-}\right)$was measured by quick tests (Merck Millipore). Samples for inorganic cations and anions as well as for dissolved organic carbon were quickly transported to the lab and frozen. Before analysis they were filtered $(0.45 \mu \mathrm{m})$ and a subsample was acidified.

\subsection{Analytics of aqueous samples}

Metals (Al, Ca, Fe, K, Mg, Mn, Na, ) were analysed in acidified solution by ICP-OES (inductive coupled plasma optical emission) spectroscopy and nitrate $\left(\mathrm{NO}_{3}^{-}\right)$by CFA (Continuous-Flow Analysis). Other anions and organic acids were measured by IC (ion chromatography) and dissolved organic carbon (DOC) was quantified by LC-OCD (liquid 
chromatography - organic carbon detection). Isotope analyses of water isotopes ${ }^{18} \mathrm{O}$, and ${ }^{2} \mathrm{H}$ were performed in selected water samples by mass spectroscopy.

\subsection{Rock characterization}

Cutting samples from the Triassic Exter formation and from the Tertiary Sand (collected during well drilling in 2016) were geochemically analysed by X-ray fluorescence (XRF), $\mathrm{X}$-ray diffraction (XRD), Scanning electron microscopy (SEM), and by mass spectrometry for total and organic carbon (TC and TOC).

A leaching experiment was conducted to estimate metal mobilization from formation rocks. For these tests, samples (TS and Exter cuttings) were dried at $105^{\circ} \mathrm{C}$ and ground to a powder. Each $5 \mathrm{~g}$ were added to $10 \mathrm{~mL}$ electrolyte $(0.5 \mathrm{M} \mathrm{NaCl})$ or to electrolyte plus tracer mix $(\mathrm{NaCl}-\mathrm{T})$. The $\mathrm{pH}$-values were measured before and after $24 \mathrm{~h}$ of continuously shaking in each sample. Afterwards, the suspensions were filtered $(0.45 \mu \mathrm{m})$ and acidified to $\mathrm{pH}<2$ for analysing Al- und Fe concentration.

\section{Results}

\subsection{Monitoring the hydraulic tests}

During the SRT the electric conductivity (EC) of the produced water increased from 40.1 to $42.0 \mathrm{mS} / \mathrm{cm}$. Dissolved oxygen (DO) and redox values decreased from 2.6 to 1.4 $\mathrm{mg} / \mathrm{L}$ and $-188 \mathrm{mV}$ to $-200 \mathrm{mV}$, respectively and the $\mathrm{pH}$ value was constant between 7.48 and 7.53. Most cations and anions varied slightly over time without any clear tendencies. Dominant ions are $\mathrm{Na}$ and $\mathrm{Cl}$ (both $>320 \mathrm{mM}$ ), followed by $\mathrm{SO}_{4}(\sim 13 \mathrm{mM})$ and bicarbonate (5.5 to $6.9 \mathrm{mM}$ ). Nitrate, $\mathrm{Al}$, and $\mathrm{Mn}$ were all at concentrations $<0.005 \mathrm{mM}$ (Fig. 2). DOC varied during the step rate test between 3.2 and $5.8 \mathrm{mg} / \mathrm{L}$, and the content of organic acids was below the detection limit.

During injection of the PPT, $\mathrm{pH}$ and EC, remained relatively constant within the three containers $(7.4-7.57 ; 42.2-42.6 \mathrm{mS} / \mathrm{cm})$. The $\mathrm{DO}$ ranged between 3 and $10 \mathrm{mg} / \mathrm{L}$ and redox between -60 and $+174 \mathrm{mV}$. Iron was generally close to detection limit with the exception of samples from container 1, where up to $3 \mathrm{mM} \mathrm{Fe}$ were measured (Fig. 2). The $\mathrm{Al}$ concentration was generally low (0.01 -0.09 mM; Fig 2).

Twelve hours later, the water was back-produced from the reservoir (PPT, pull phase). The $\mathrm{pH}$ and EC were stable $(7.3$ to 7.6 and $42.6 \mathrm{mS} / \mathrm{cm})$ and the redox decreased from +23 $\mathrm{mV}$ to $-64 \mathrm{mV}$. The nitrate tracer was measurable from the very beginning in the samples and increased until production of $55.2 \mathrm{~m}^{3}$ to a maximum of $0.89 \mathrm{mM}$. Afterwards it decreased down to $0.08 \mathrm{mM}$ (after $300 \mathrm{~m}^{3}$; Fig. 2). $\mathrm{Na}, \mathrm{Cl}, \mathrm{Ca}, \mathrm{Mg}$, and $\mathrm{SO}_{4}$ correlated roughly with each other and the DOC was about $5 \mathrm{mg} / \mathrm{L}$. While the Fe concentration remained constantly low (about $0.0002 \mathrm{mM}$ ), Al varied strongly: until production of $19 \mathrm{~m}^{3}$ it remained relatively constant $(0.02 \mathrm{mM})$ then increased afterwards to up to $3.9 \mathrm{mM}$ (at $50.5 \mathrm{~m}^{3}$ ) followed by an immediate decrease down again to $0.02 \mathrm{mM}$ at $52.8 \mathrm{~m}^{3}$, which remained constant until production of $207 \mathrm{~m}^{3}$ (here, the pump was switched on again a production break), when it increased again to $4.7 \mathrm{mM}$ at $225 \mathrm{~m}^{3}$, dropped down to $0.9 \mathrm{mM}$ at $262 \mathrm{~m}^{3}$ and roughly remained at this order of magnitude until the end of the production phase.

The isotopic ratios of water of ten fluid samples collected during the tests showed very constant data of $\delta \mathrm{D}$ of about $-61 \%$ SMOW and $\delta^{18} \mathrm{O}$ of $-9 \%$ SMOW. 


\subsection{Rock characterization and leaching test}

The rock samples from the Exter Fm. are predominantly composed of quartz with traces of kaolinite, montmorillonite, and calcite. The TS contains pieces of coal, quartz and pyrite. The elemental composition of the two rock types is given in Table 1.

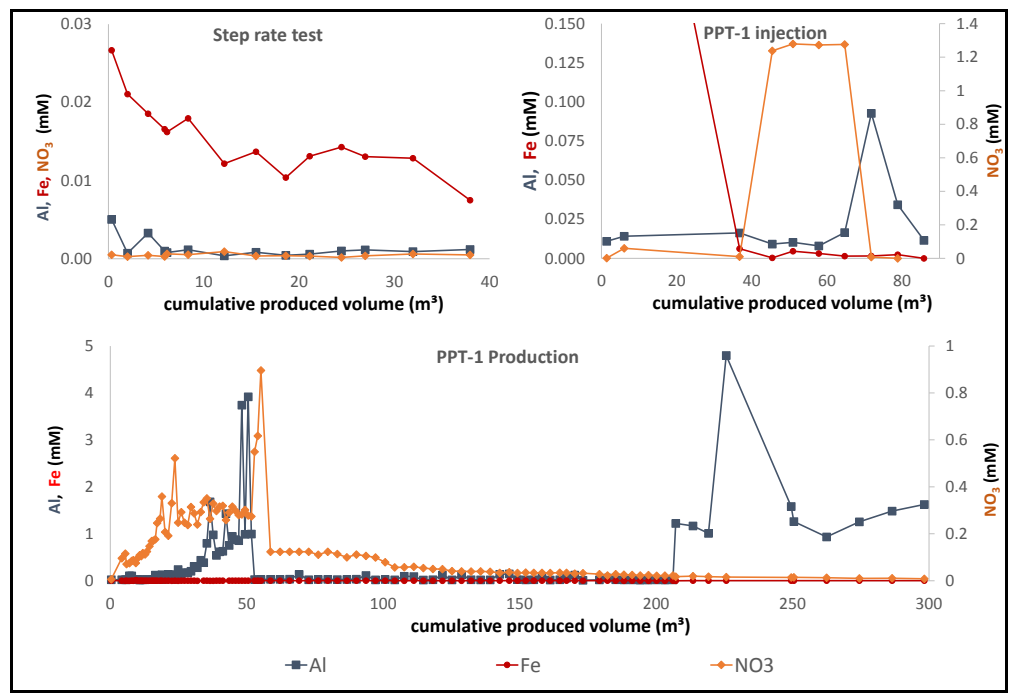

Fig. 2. Concentrations of $\mathrm{Fe}, \mathrm{Al}$, and $\mathrm{NO}_{3}$ during SRT, PPT-injection and PPT production.

Table 1. XRF analysis of Exter (Ex) and Tertiary Sands (TS) cuttings.

\begin{tabular}{|c|c|c|c|c|c|c|c|c|c|c|}
\hline & $\mathrm{SiO}_{2}$ & $\mathrm{Al}_{2} \mathrm{O}_{3}$ & $\mathrm{Fe}_{2} \mathbf{O}_{3}$ & $\mathrm{CaO}$ & $\mathbf{M g O}$ & $\mathrm{K}_{2} \mathrm{O}$ & $\mathrm{Na}_{2} \mathrm{O}$ & $\mathrm{TiO}_{2}$ & $\mathrm{SO}_{3}$ & $\mathrm{Cl}$ \\
\hline $\mathbf{E x}_{1}$ & 63.9 & 20.8 & 3.54 & 3.44 & 2.44 & 1.65 & 1.55 & 1.17 & 0.7 & 0.35 \\
\hline $\mathbf{E x} 2$ & 70.7 & 19.1 & 2.45 & 1.78 & 1.75 & 1.31 & & 1.07 & 0.11 & 0.16 \\
\hline $\mathbf{T S}$ & 42.8 & 17.75 & 23.32 & 0.95 & 3.1 & 2.03 & 1.86 & 0.75 & 5.5 & 1.14 \\
\hline
\end{tabular}

The carbon content of the Exter Fm. samples was 3 to $4 \%$ (TIC as calcite) and 0.5 to $1.8 \%$ TOC, whereas the TS contained a TOC of 6.4 and $9 \%$ TC (as calcite). Analysis by $\mathrm{SEM} / \mathrm{EDX}$ revealed that components in the Exter Fm. are indeed mainly quartz and aluminosilicates. The TS also contained gypsum and pyrite.

The $\mathrm{pH}$ measured both, immediately and 24 hours after the rock cuttings were added into the electrolytes remained around neutral for the Exter Fm samples but decreased strongly for the TS ( 4; Fig. 3). Similarly, the Fe and Al concentrations increased strongly in the TS samples but remained low after reaction with the Exter (Fig. 3). The effect of the tracer-mix on $\mathrm{pH}, \mathrm{Al}$, or Fe concentration was, however not significant. 


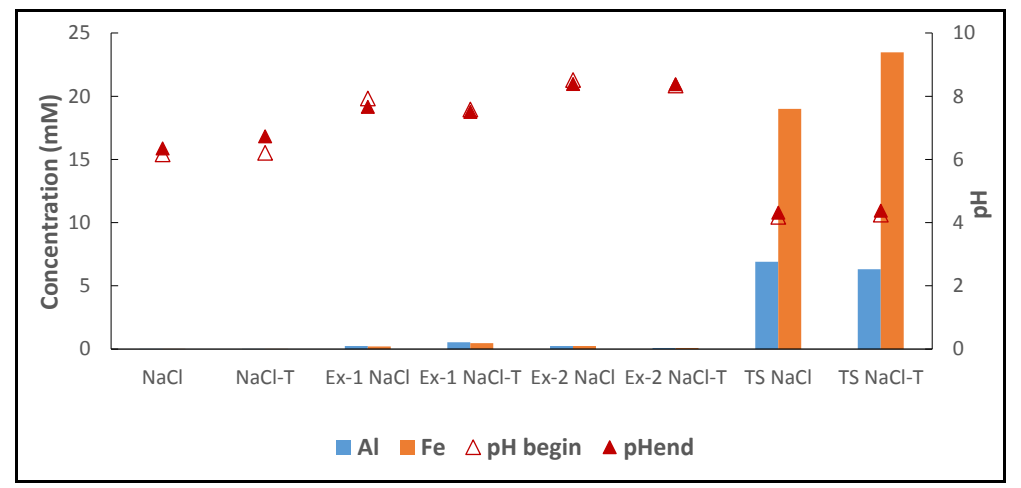

Fig. 3. Release of $\mathrm{Fe}$ and $\mathrm{Al}$ after reaction for $24 \mathrm{~h}$ with $0.5 \mathrm{M} \mathrm{NaCl}$ or $\mathrm{NaCl}+\mathrm{Tracer}(\mathrm{T})$ mix.

\section{Discussion and Conclusion}

Since the isotopic ratios of water $\left(\delta \mathrm{D}\right.$ and $\left.\delta^{18} \mathrm{O}\right)$ remained constant in all collected aqueous samples, a well-mixed groundwater that was in equilibrium before well drilling and injection tests can be assumed for the site. The mobilization of $\mathrm{Al}$ from the reservoir during the PPT production phase can be explained by the following processes: The injected water passed - possibly via the gravel pack - into the TS (Fig.1). The pyrite $\left(\mathrm{FeS}_{2}\right)$ within this formation undergoes oxidation induced by the $\mathrm{O}_{2}$-rich water. This oxidation possibly began already during drilling the well in 2016. Pyrite oxidation [2] was followed by precipitation of $\mathrm{Fe}$ (III) hydroxides (explaining why hardly any Fe was measured) and the release of protons. The acid would be consumed by dissolution of clay minerals (explaining the neutral $\mathrm{pH}$ value in collected field samples), which in turn releases Al. Based on the fact that $\mathrm{Al}^{3+}$ is not stable at neutral $\mathrm{pH}$ (it precipitates either as gibbsite or as alunite) we assume the formation of colloids consisting of gibbsite $\left(\mathrm{Al}(\mathrm{OH})_{3}\right.$, alunite $\left(\mathrm{KAl}_{3}\left(\mathrm{SO}_{4}\right)_{2}(\mathrm{OH})_{6}\right)$, or bound to the organic phase. The colloidal $\mathrm{Al}$ species are of small particle size (e.g. about $50 \mathrm{~nm}$; [3]) and would thus pass the filters $(<0.45 \mu \mathrm{m})$ but would re-dissolve after acidification before ICP analysis.

These processes and observations demonstrate the strong impact of oxygen input on water composition during hydraulic aquifer testing. The strong release of Al could result in enhanced precipitation and thus clogging of the reservoir pores during future operation of the site as ATES.

We kindly acknowledge Romy Siemon, Dominika Orenczuk, Oliver Rach, Iris Pieper, Mora Fernandez-Jurado, Tanja Ballerstedt, Kristin Günter, Andrea Vieth-Hillebrand, Anja Schleicher, Birgit Plessen, Silvia Pinkerneil, and the TU Delft department of Material Science and Engineering.

\section{References}

1. S. Regenspurg et al., Env Earth Sci. 77, 13 (2018)

2. D.K. Nordstrom, Aqueous pyrite oxidation and the consequent formation of secondary iron minerals, in Acid Sulfate Weathering, J.A. Kittrick, D.S. Fanning, L.R. Hossner (Eds.) Soil Sci Soc Am Spec Pub 10, 37-55 (1982)

3. M.A. Schlautman, J.J. Morgan, Geochim. Cosmochim Acta 54, 20 (1994) 